\title{
READING JOHN PAUL II'S FIDES ET RATIO IN THE LIGHT OF JÜRGEN HABERMAS' POSTMETAPHYSICAL THINKING: TOWARDS A DIALOGUE WITH THE SECULAR WORLD
}

\author{
Jose Conrado A. Estafia \\ Immaculate Heart of Mary Seminary \\ Tagbilaran City, Bohol, Philippines
}

\begin{abstract}
The paper suggests that the Encyclical Letter Fides et Ratio of John Paul II can be read today in the light of the so-called postmetaphysical thinking recommended by Jürgen Habermas, and doing this would lead the Catholic Church to a dialogue with the secular world. While being respectful to the autonomy of the philosophical disciplines, John Paul II makes an appeal to philosophers and all teachers of philosophy to courageously recover the proper end of every philosophical inquiry, that is, authentic wisdom and truth, including metaphysical truth. The encounter between faith and reason has always been a drama of separation and reconciliation. Becoming autonomous to the point of being a "godless discipline," the modern thought completely separated itself from revealed truth, cutting itself off from faith and theology. This was, in fact, the main point of the Enlightenment, that is, to release oneself from the clutches of religion. However, the revival of Catholic thought in the second half of the nineteenth century, as Edith Stein observes, opens a new possibility of finding a common meeting ground between the reborn Medieval philosophy and the newly created twentieth-century philosophy. Habermas' recommendation of a post-metaphysical thinking, which follows the concept of genealogy, has a role to play in the dialogue between religion and the secular world. Through dialogue, we can now promote an awareness of complementarity between the two sides. Hence, the appeal of John Paul II in Fides et Ratio finds new impetus to carry out this dialogue further and without fear.
\end{abstract}

\section{INTRODUCTION}

While in a bookshop in Vienna, my attention was caught by Jürgen Habermas' latest work, a two-volume book consisting of 1738 pages all in all, which was only released last September 2019, and I think the English edition is yet to come out. 
Together with Heidegger's Pathmarks (Wegmarken), I also bought these two volumes of Habermas.

The title of this book is Auch eine Geschichte der Philosophie (Habermas 2019). Volume I is subtitled as Die Okzidentale Konstellation von Glauben und Wissen; volume II's subtitle is Vernünftige Freiheit. Spuren des Diskurses über Glauben und Wissen. The theme of these volumes has preoccupied the years of Habermas' retirement (Habermas 2019, 16). ${ }^{1}$ In a conversation with Habermas, Eduardo Mendieta comments:

For over two decades already, you have been arguing for the enlightenment of philosophical thinking in terms of 'post-metaphysical thinking.' You have characterized postmetaphysical thinking in terms of the rearticulation of reason as procedural - that is, thoroughly linguistified - and at the same time historically situated, which has led to the deflation of the extraordinary. Postmetaphysical thinking, thus, is parsimonious, fallibilistic, and humble in its claims. In your recent work, however, you claim that post-metaphysical thinking forces us to take the next step namely, the post-secular step" (Habermas 2017, 61-62; 2012). ${ }^{2}$

With this development, I wanted to read again John Paul II's Fides et Ratio in the light of Habermas' postmetaphysical thinking. I admit that this is not an easy work for me, considering that I still have a limited knowledge of the kind of thinking recommended by Habermas. There was a symposium on the work of Habermas on the relation between post-metaphysical thinking and religion held on 23-24 October 2009 at New York University; and in referring to the contributions of the said symposium, Habermas $(2012,120-182 ; 2017,77-121)$ made a reply published in the second volume of his book called Nachmetaphysisches Denken II. Aufsätze und Repliken. He admits that the "participants had to refer to a position that is not yet sufficiently developed" (Habermas 2017, 77). ${ }^{3}$ And there is always a drawback when "discussing ideas that are still in flux," he says.

The present paper suggests that the Encyclical Letter Fides et Ratio of John Paul II can be read today in the light of the so-called postmetaphysical thinking of Habermas, and doing this would lead the Catholic Church to a dialogue with the secular world. In this document, John Paul II (1998, n. 106) makes an appeal to "philosophers, and to all teachers of philosophy, asking them to have the courage to recover, in the flow of an enduringly valid philosophical tradition, the range of authentic wisdom and truth-metaphysical truth included-which is proper to philosophical inquiry." "The Church," John Paul II continues, "follows the work of philosophers with interest and appreciation, and they should rest assured of her respect for the rightful autonomy of their discipline." But this dialogue, and may have been anticipated by the publication of the Encyclical of John Paul II, is one that is already situated in a post-secular society, coming from a postmetaphysical thinking. Habermas $(2017,78)$ opines, "Religious traditions differ from philosophy in their mode of belief and in how they justify taking-to-be-true, but above all in the fact that the ritual practices of a religious community provide a stabilizing anchor for faith." 
Ritual practices providing a stabilizing anchor for faith? That would be a big theme, I guess, for future investigation. ${ }^{4}$

John Paul II (1998, n. 106) encourages "believers working in the philosophical field to illumine the range of human activity by the exercise of a reason which grows more penetrating and assured because of the support it receives from faith." And yet, Habermas' recommendation of a postmetaphysical thinking has given the Catholic Church an additional vibrancy to this dialogue between faith and reason. Habermas (2017, 78-79) writes, thus:

It is precisely the historical 'simultaneity' of the formation of secular thinking and religious consciousness, which in the meantime have diverged into opposites, which leads me to explore the shared genealogy of postmetaphysical thinking and major world religions. For what still sets philosophy apart from the objectifying sciences today is the selfreferential question about how we, as human beings, should understand ourselves (and how 'modernity' should be understood).

This may not be an exhaustive discussion, but perhaps it can serve as an introduction to a further investigation and consideration of the subject matter at hand.

\section{FAITH AND REASON: THE DRAMA OF SEPARATION AND RECONCILIATION}

Chapter IV of Fides et Ratio speaks of the relationship between faith and reason. It opens with the important moments in the encounter of faith and reason. In this chapter, John Paul II (1998, n. 42) says: "The fundamental harmony between the knowledge of the faith and the knowledge of philosophy is once again confirmed. Faith asks that its object be understood with the help of reason, and at the summit of its searching reason acknowledges that it cannot do without what faith presents." The chapter also highlights the enduring originality of the thought of St. Thomas Aquinas because of his teachings and his dialogue with the Arab and Jewish thought of his time. His encounter with ancient philosophy, especially the philosophy of Aristotle, is proof that a harmonious relationship between faith and reason can exist (John Paul II 1998, n. 43).

The opening statement of Fides et Ratio rightly claims: "Faith and reason are like two wings on which the human spirit rises to the contemplation of truth; and God has placed in the human heart a desire to know the truth - in a word, to know himself - so that, by knowing and loving God, men and women may also come to the fullness of truth about themselves." In paragraph 17, John Paul II writes: "There is thus no reason for competition of any kind between reason and faith: each contains the other, and each has its own scope for action."

However, the modern ${ }^{5}$ man is unique in the sense that what has long been upheld by him to be true now becomes subject to doubt and denial. René Descartes $(1984,12)$ dramatizes this in the opening lines of his Meditations. He writes thus,

Some years ago, I was struck by the large number of falsehoods that I had accepted as true in my childhood, and by the highly doubtful nature 
of the whole edifice that I had subsequently based on them. Once in the course of my life, I realized that it was necessary to demolish everything completely and start again right from the foundations if I wanted to establish anything at all in the sciences that was stable and likely to last.

The "theocentric" position of Medieval times no longer holds at the dawn of the Age of Enlightenment. In "Answer to the Question: What is Enlightenment?," Immanuel Kant $(2001,141)$ puts it, "I have emphasized the main point of Enlightenment, that is of man's release from his self-incurred minority, primarily in matters of religion."

However, it must be made clear here that the modern position is not really to abandon God. ${ }^{6}$ There is only a shift in the approach. In fact, the Cartesian doubt is only methodical. ${ }^{7}$ Descartes' aim is to establish the foundation of knowledge/science. What he proposes at the beginning of his Meditations is very radical - universal doubt. Descartes (1985, 193-194) outlines the principles of this methodical doubt in the Principles of Philosophy. His first certitude is the existence of the cogito, and the existence of God only comes as the second certitude. But this method is not without a consequence. John Paul II (2005, 8-9) has this criticism of Descartes' method, saying:

...we have to go back to the period before the Enlightenment, especially to the revolution brought about by the philosophical thought of Descartes. The cogito, ergo sum (I think; therefore, I am) radically changed the way of doing philosophy. In the preCartesian period, philosophy, that is to say, the cogito, or rather the cognosco, was subordinate to esse, which was considered prior. To Descartes, however, the esse seemed secondary, and he judged the cogito to be prior. This not only changed the direction of philosophizing, but it marked the decisive abandonment of what philosophy had been hitherto, particularly the philosophy of Saint Thomas Aquinas, and namely the philosophy of esse.

There is in Descartes a clear departure from the Medieval mind. Michel Foucault $(1984,39)$ describes this modern position as a "discontinuity of time: a break with tradition, a feeling of novelty, of vertigo in the face of the passing moment." $\mathrm{He}$ wonders whether one may describe modernity as an "attitude" rather than as an epoch. By "attitude," Foucault $(1984,39)$ means "a mode of relating to contemporary reality; a voluntary choice made by certain people; in the end, a way of thinking and feeling; a way, too, of acting and behaving that at one and the same time marks a relation of belonging and presents itself as a task." The modern man "tries to invent himself," says Foucault $(1984,42)$ following Baudelaire. In a word, the interpretation of the world and everything begins with the man himself. John Paul II (2005, 8-9) continues:

Previously, everything was interpreted from the perspective of esse, and an explanation for everything was sought from the same standpoint. God as a fully Self-sufficient Being (Ens subsistens), was believed to be 
the necessary ground of every ens non subsistens, ens participatum, that is, of all created beings, including man. The cogito, ergo sum marked a departure from that line of thinking. Now the ens cogitans enjoyed priority. After Descartes, philosophy became a science of pure thought: all esse - both the created world and the Creator - remained within the ambit of the cogito as the content of human consciousness. Philosophy now concerned itself with beings qua content of consciousness and not qua existing independently of it.

John Paul II proposes the necessity of regarding "the reality of the Absolute Being and also the reality of being human, that is, being a creature." He warns that if ever we do not begin from a "realist" position, "we end up in a vacuum" (John Paul II $2005,12)$. That is why, in the opening page of Fides et Ratio, John Paul II proclaims that faith and reason are two inseparable wings in the contemplation of truth. He declares, empathically, that the Church "sees in philosophy the way to come to know fundamental truths about human life" (John Paul II 1998, n. 5). Moreover, the Church "considers philosophy an indispensable help for a deeper understanding of faith and for communicating the truth of the Gospel to those who do not yet know it" (John Paul II 1998, n. 5). In Pastores Dabo Vobis, John Paul II (1992, n. 52) highlights philosophy as a guarantor of the certainty of truth.

And yet, philosophy is not enough since a philosophical system can only present a partial and imperfect view of reality. If it claims to be total, then it leads to what John Paul II (1998, n. 4) calls "philosophical pride." Remember that Boethius $(1999,109)$ has decreed "that the imagination and the senses ought to yield to reason, so we would regard it as most just that the human reason should defer to the divine mind." To Boethius, reason needs faith. "So if we can," he continues, "let us raise ourselves to the peak of that highest understanding, for there the reason will look upon what she cannot of herself observe: that is, how even things which have no certain outcome are witnessed by an unerring and precise foreknowledge, a foreknowledge which is not mere opinion, but rather the simplicity of highest knowledge confined by no bounds" (Boethius 1999, 109).

The tension between faith and reason has always been there; though, in Medieval times, their separation was not really a problem due to the "organic link between theology and philosophy." But soon, there occurred this "fateful separation." "Exaggerated rationalism" separated philosophy totally from faith, another consequence of which was the complete mistrust of reason itself (John Paul II 1998, n. 45). John Paul II (1998, n. 46) says, "It is not too much to claim that the development of a good part of modern philosophy has seen it move further and further away from Christian Revelation, to the point of setting itself quite explicitly in opposition." In his pre-papal philosophical work entitled The Acting Person, Pope John Paul II (1979, vii) unravels the details of a "crucial state of affairs" and elucidates the basic problems involved. He addresses the major issues concerning life, nature, and the existence of the human being. Most often, we observe that philosophy has always been a reflection upon theories about theories. As the pope says in the Agenda for the Third Millennium:

The 'learned' and the 'clever' have worked out their own view of 
God and the world, and they are disinclined to change it. They believe that they know all there is to know about God, that they have the final answer, that they have nothing more to learn. Moreover, this is why they reject 'the good news,' for it strikes them as quite alien and conflicting with the main tenets of their Weltanschauung. The Gospel message proposes certain paradoxical reversals which their 'common sense' cannot accept (John Paul II 1996, 5-6).

In his book, Easter Vigil and other poems, John Paul II (1979) has written a beautiful poem that is related to the matter above. It goes this way:

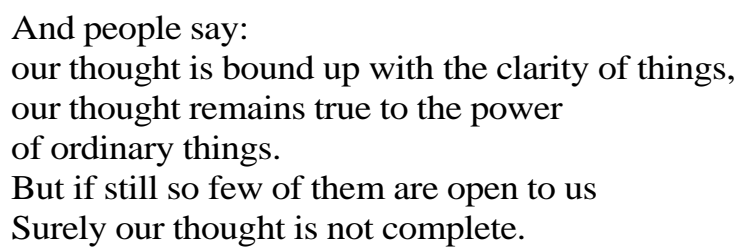

The approach of the pope in the The Acting Person is not similar to that of Descartes. If in Descartes man is revealed in thinking, in John Paul II, we find the actual enacting of man's existence. Following the Husserlian dictum "back to the things themselves," the pope emphasizes the everyday experience of man and his concrete wholeness (Weigel 2001, 127). Contrary to Descartes, one's existence cannot be doubted. Pope John Paul II $(1995,34)$ says in his bestseller book, Crossing the Threshold of Hope: "It is, therefore, possible to speak from a solid foundation about human experience, moral experience, or religious experience. And if it is possible to speak of such experiences, it is difficult to deny that, in the realm of human experience, one also finds good and evil, truth and beauty, and God." Man is approached through action through his concrete experiences. The man who philosophizes is an acting person - the man who is capable of knowing God through the use of his God-given intellect.

The drama of the separation between faith and reason reminds me of Edith Stein's observation. ${ }^{8}$ John Paul II mentions her in Fides et Ratio as one of those "recent thinkers" who have bravely managed to harmonize philosophy and the Word of God in their research. ${ }^{9}$ Stein describes modern thought as a dissociation from the problem of being whose focus is the problem of knowledge. ${ }^{10}$ By centering itself on the problem of knowledge, claims Stein, modern thought cuts itself off from faith and theology. It thus completely separates itself from revealed truth. Revelation is no longer the standard by which modern philosophy tests its findings (Stein 2002, 4-5; 2006, 13). It has become autonomous and to the point of becoming a "godless discipline." Philosophy then has been divided into two contending camps: modern philosophy and Catholic-scholastic philosophy (Stein 2002, 5). The latter speaks of philosophia perennis, which outsiders consider "a private affair of theological faculties, seminaries, and colleges of religious orders." To them, philosophia perennis is abstract and lifeless. ${ }^{11}$ However, a reconciliation of these two contending camps is not without hope. Stein is right in pointing out that there is a revival of Catholic 
thought in the second half of the nineteenth century. Prior to this, Catholic scholars have lost connections with their "own great past, for they were in large measure dependent on modern thought" (Stein 2002, 5).

The Catholic Church's revival of the study of the texts of St. Thomas in Catholic institutions of higher learning was astonishing of Stein. The discovery of unpublished manuscripts sleeping in European libraries has revealed: "a whole forgotten world - a rich and dynamic world - which holds much promise for the future" (Stein 2002, 56). ${ }^{12}$ Stein is convinced of the relevance of the medieval Ages' great Catholic thinkers to our present condition; they have something valuable to tell us. It is an admirable scholarly achievement, but for Stein, the task is far from complete.

However, one can look at the problem from a different angle. Stein has pointed out that while Christian philosophy has awakened from its slumber, modern philosophy made a great discovery that the trail it followed for the past three centuries only brought it into a blind path. The return to Kant with the neo-Kantians was not enough, Stein contends. This would gradually bring modern philosophy to turn once more to the problem of being and reality. Thus the long despised term ontology, the science of being, was vindicated. Ontology again appears in the phenomenology of Edmund Husserl and Max Scheler and in the philosophy of existence of Martin Heidegger and Hedwig Conrad-Martius (Stein 2002, 5-6; 2006, 14-15). Stein (2002, $6-7 ; 2006,15)$, on her part, sees the possibility of a "common meeting ground" between "the reborn philosophy" of the Medieval and "the newly created philosophy of the twentieth century."

But will there be a reconciliation in the future? If there will be, how? John Paul II (1998, n. 48) has a moving appeal in Fides et Ratio: "This is why I make this strong and insistent appeal - not, I trust, untimely - that faith and philosophy recover the profound unity which allows them to stand in harmony with their nature without compromising their mutual autonomy. The parrhesia of faith must be matched by the boldness of reason." Below we shall see the possibility of religion's dialogue with the secular world.

\section{A DIALOGUE WITH THE SECULAR WORLD}

I believe that Habermas' recommendation of a "postmetaphysical thinking" has a role to play in the dialogue between religion and the secular world. In this section, we shall try to understand what secularism is all about. Charles Taylor $(2007,2)$, in his comprehensive book A Secular Age, understands secularity or secularism in three senses. First, secularity is understood in terms of "public spaces." In earlier societies (especially in the West), "religion was 'everywhere,' was interwoven with everything else, and no sense constituted a separate 'sphere' of its own." In earlier ages, there was this marriage between "throne" and "altar," which was the case during the time of Baroque Catholicism - that age of faith or piety. Secularity, in this sense, would mean that the "various spheres of activity - economic, political, cultural, educational, professional, recreational - the norms and principles we follow, the deliberations we engage in, generally do not refer us to God or any religious beliefs." The basis of these various human activities is already internal to them; that is, the "rationality" of each 
sphere." For example, within the economy, what is referred to is "maximum gain." In politics, "the greatest benefit to the greatest ods." Hence, through the clergy, the Church has no more authority over these realms, like, for instance, the Church's ban on usury or the enforcement of orthodoxy in the political arena, Taylor comments. However, take note that in this understanding of secularism, it is still compatible with believing in God and engaging in "autonomous social spheres."

The second meaning of "secularity consists in the falling off of religious belief and practice, in people turning away from God, and no longer going to Church." This is what is happening in western European countries, so that even "those who retain the vestigial public reference to God in public space" are no longer exempted from this condition, claims Taylor. Since the Renaissance and definitively after the Age of Enlightenment, there is a development of scientific rationality in Europe. According to Joseph Ratzinger (Pope Benedict XVI), a new culture has been developed in this way of rationality, which banishes God from the public consciousness. People of this culture either deny God totally or consider his existence as unprovable, uncertain, and as a matter of fact, God is now classified as being irrelevant to the public. ${ }^{13}$

The third meaning is closely related to the second and not without connection to the first. The keyword here is "conditions of belief." In this understanding, the shift to secularity is "a move from a society where belief in God is unchallenged and indeed, unproblematic, to one in which it is understood to be one option among others, and frequently not the easiest to embrace" (Taylor 2007, 3). This third sense is the main focus of Talyor's book, A Secular Age. In encapsulating this type of secularity, he writes that "the change I want to define and trace is one which takes us from a society in which it was virtually impossible not to believe in God, to one in which faith, even for the staunchest believer, is one human possibility among others." For a believer in this society, abandoning one's faith may be inconceivable, but he or she cannot dismiss the fact that even if others have no faith, they are not necessarily "depraved, or blind, or unworthy." In this society, "belief in God is no longer axiomatic." There are already many alternatives, and in this "milieu," observes Taylor, "it may be hard to sustain one's faith." Moreover, indeed, the feeling of giving it up is inevitable, even if losing such faith would be lamentable. This situation already started at least in the midnineteenth century, Taylor claims. Faith does not even qualify as a possibility for many others, and this is true for millions today.

However, the possibility of a dialogue between religion and the secular world always remains. On January 19, 2004, Habermas had a dialogue with Joseph Ratzinger at the Catholic Academy of Bavaria in Munich. In that dialogue, Habermas claims that "philosophy has good reasons to be willing to learn from religious traditions" (Ratzinger and Habermas 2006, 42; 2011, 30).

Habermas $(2006,46-47$; 2011, 33) proposes a "postsecular society" and suggests a harmony between religion and the secular world. Ratzinger (2006, 77; $2011,56)$ broadly agrees with Habermas' remarks regarding "postsecular society," which is "about the willingness to learn from each other, and about self-limitation on both sides," while deploring the existence of pathologies in religion and of reason. ${ }^{14}$ Regarding the former, Ratzinger says that "religion must continually allow itself to be purified and structured by reason; and this was the view of the Church Fathers, too (Ratzinger and Habermas 2006, 77; 2011, 56)." Regarding the latter, he says that 
"reason, too, must be warned to keep within its proper limits, and it must learn a willingness to listen to the great religious traditions of mankind" (Ratzinger and Habermas 2006, 78; 2011, 56). Ratzinger adds that reason is destructive if it cuts completely from this relatedness. There is then a "necessary relatedness between reason and faith and between reason and religion, which are called to purify and help one another" (Ratzinger and Habermas 2006, 78; 2011, 57). Now we proceed to Habermas' recommendation of a postmetaphysical thinking.

\section{HABERMAS’ POSTMETAPHYSICAL THINKING}

What does Habermas mean by postmetaphysical thinking? Habermas, a known disciple of Max Weber, has surprised many people by his challenge for the "secular society" to have a fresh "understanding of religious convictions." The philosopher poses this challenge to the secular society during his reception of the Peace Prize of the German Booksellers, just three weeks after the September 11, 2001, terrorist attacks (Ratzinger and Habermas 2006, 11; 2011, 10).

In clarifying what "post-secular" means, Habermas $(2017,63)$ replies that he is using this "expression to describe modern societies, which must assume that religious groups will continue to exist and that different religious traditions will remain relevant, even if the societies themselves are largely secularized." For him, "postsecular" is a sociological predicate and not genealogical. Later on, we shall see what he meant by "genealogical." The first chapter of volume I of Auch eine Geschichte der Philosophie (title: "Zur Frage einer Genealogie nachmetaphysischen Denkens" [Towards the Question of a Genealogy of Postmetaphysical Thinking]) highlights an interesting English quotation: "The idea of a self-limiting secularization, reinstated as a regulative principle of modernity, would reopen and perpetuate the mutual interrogation of philosophy, science, and religion" (Habermas 2019, 23). Habermas $(2017,62)$ conceives postmetaphysical thinking as remaining "secular in a situation depicted as 'post-secular'; but, in this different situation, it may become aware of a secularistic self-misunderstanding." Meaning, the participants are already aware of their own limitations.

Earlier, we have seen how modern philosophy cuts itself off from faith and theology. The first chapter of volume I of this recent book of Habermas has this section: "Krisenszenarien und Verfallsgeschichten in philosophischen Großtheorien des 20. Jahrhunderts." We can find here a review of the influential philosophies in the first half of the 20th century. Through the "diagnosis of signs of deterioration," which have been getting more critical in the modern age, Habermas makes an attempt to examine the theoretical approach and exemplary understanding of these philosophies. Without intending to be exhaustive, we just mention the philosophers and the corresponding themes reviewed by Habermas: Carl Schmitt (the drama of the Christian history of salvation with the secularization of the authority of the state, the Catholic Church's fall from power [der Entmachtung] and the concluding stage of political liberalism); Leo Strauss (the crisis of state and society manifesting itself in similar phenomena but explained differently, that is, coming from the dissolution of the classical natural law concept of politics into "the purposively rational application 
of abstract power" [die zweckrationale Verwendung abstrakter Macht] and stable "system of rule" ensuring above all the negative liberties of citizens [die negativen Freiheiten der Bürger] by means of positive law); Karl Löwith (the secular philosophy of history, coming from Augustine to Joachim of Fiore and Bossuet's ${ }^{15}$ development of "salvation-historical thought" [heilsgeschichtliche Denken] with Vico and the French philosophers of the Enlightenment, leading to a historicism that supposedly elucidates "the totalitarian disinhibition of political violence" [die totalitäre Enthemmung der politischen Gewalt]); and Martin Heidegger (the turn of Descartes to the philosophy of the subject [Subjektphilosophie] as the key to "the expansion of a way of thinking" [die Ausbreitung einer Denkform] with which "the oblivion of being" [die Seinsvergessenheit] darkens "to the metaphysical fate of separation from God" [zum metaphysischen Verhängnis der Gottesferne] (Habermas 2019, 40).

Aside from the four philosophers mentioned above, Habermas has included the left-wing Hegelians like Georg Lukács, Ernst Bloch, Walter Benjamin, and the exponents of the Frankfurt School. For these philosophers, the solution to the "universal pull of capitalist reification" is not to return to the Roman roots of Catholicism or the classics or origins of Greek philosophy, but to make use of the revolutionary "childbirth" (Entbindung) accumulated in the modern age, but considered temporarily as a distorted potential. ${ }^{16}$

Modernity distances itself from everything that has been. We have seen earlier in a brief exposition, the separation of modernity from faith. It has already freed itself from the clutches of religion. In this new book of Habermas $(2019,41)$, we can read this bold pronouncement: "Die Moderne ist die Krise." Habermas makes a review of the theories of the $20^{\text {th }}$ century, which are offering us a substantial "diagnosis of the time" by renewing "dried-up sources" - be it the religious, the Roman-Greek, or the mythical past. However, the manner of presentation is no longer that of the Renaissance. Interestingly, Habermas claims that from the crisis itself, salvation (Heil) is openly breaking. This is the summary of the results of the four diagnoses above (Cf. Habermas 2019, 63-64): ${ }^{17}$ 1. A secularized state power and developed democratic constitutional state (Carl Schmitt); 2. A positive legal order - subjective rights for everyone and the priority of private scope of action over binding norms (Leo Strauss); 3. Historical consciousness - interpreting the past from the horizon of the future and alienating people from nature (Karl Löwith); and 4. Enforced experimental and mathematical natural sciences and the transformative power of scientific and technical progress (Martin Heidegger). And finally, Habermas mentions the crisis of modernity, attributable to its modern traits: 1 . The losing of society's center and the ability to act due to the neutralization of the political; 2 . The disintegration of the normative background agreement and the social cohesion of society; 3. The totalitarian derailments of a collective mobilization of society in the sign of political ideologies of progress drawing from unacknowledged religious motives; 4 . The social pathologies of the dominion of technology (in the broad metaphysical sense).

Earlier in the foreword, Habermas $(2019,9)$ poses this question: "Was kann heute noch ein angemessenes Verständnis der Aufgabe der Philosophie sein?" (What can be an adequate understanding of the task of philosophy today?). From the crisis of modernity, what is then the task of philosophy? Habermas $(2017,92)$ recalls that "[t]he Axial Age revolution in worldviews and the separation between secular and 
religious thought in modern Europe represent caesuras in the genealogy of postmetaphysical thinking and at the same time stages in social evolution."

Modernity's separation of secular and religious thought is not the case in the Axial Age (Achsenzeit). As Habermas (2019, 14-15) suggests, philosophy, since its inception, is ranked as one of the "enumerable metaphysical and religious worldviews of the Axial Age," and that has become the fate of philosophy. When Christian Platonism emerged in the Roman Empire, the "discourse on belief and knowledge" (der Diskurs über Glauben und Wissen) regained "a constitutive role" in the further development of the philosophical heritage of the Greeks. Such a discourse has guided Habermas for the genealogy of post-metaphysical thinking, which intends to expose the complementarity of philosophy and Christian dogmas, which are conceptually expressed in philosophical terms. Post-metaphysical thinking would show philosophy's appropriation of the "essential contents from religious tradition" (wesentliche Gehalte aus religiön Überlieferung) and their transformation "into justifiable knowledge" (in begründungsfähiges Wissen).

The subsequent secular thinking of Kant and Hegel, precisely, owes from "this semantic osmosis" (dieser semantischen Osmose) the theme of "rational liberty" (vernünftiger Freihiet) and the standard basic concepts of practical philosophy which are still relevant today. When transferring the "semantic contents of biblical origin" (semantische Gehalte biblischen Ursprungs) to the basic concepts (Grundbegriffe) of postmetaphysical thinking, after the uprooting of Greek cosmology, it is now decisive for philosophy to ask what to trust and what can be trusted from this "transformed legacy of religious origin" (transformierten Erbe religiöser Herkunft), no matter how blatant its secular character. Interpreting this religious legacy only from the empirical or naturalistic perspective makes postmetaphysical thinking one-sided (Habermas $2019,15)$. Contrary to this assumption is the deep caesura (der tiefe Einschnitt) in the young Hegelians' radical criticism of religion. With historical and material thinking, the young Hegelians turned away from Hegel despite all continuity without abandoning their interest in the traces of reason in history and in the general understanding of their philosophical work, which aims at promoting "reasonable living condition." A professional understanding of the self as such can be sustained with "a plausible reading of the history of philosophy" by understanding history as "an irregular sequence of contingently triggered learning processes across abysses" (Habermas 2019, 16).

Habermas $(2017,93)$ claims that "the genealogy that leads from the modern age, via the symbiosis of Greek metaphysics with Christianity, back to complementary origins in the Axial Age should serve as a corrective to a particular self-understanding of philosophy that is dominant in the profession, and by no means only among hardcore naturalists." It is now being guided by "the problematizing intention of enlightening secular thought concerning the Enlightenment's blinkered secularistic self-understanding," Habermas continues. The genealogical presentation would clarify "the contingent circumstances" (die kontingenten Umstände) challenging each of the "learning processes" (Lernprozessen) and the "reasons that speak for a comprehesive concept of reason and to hold on (festzuhalten) to a correspondingly demanding (anspruchsvollen) self-understanding of the philosophical thinking" (Habermas 2019, 16). We can learn from the architects of the "decadent history of 
modernity" (Verfallsgeschichte der Moderne) and from "modernity's self-assertion" (Selbstbehauptung der Moderne), and conclusions can be drawn from "the deficits of this heated debate about self-understanding for the creation of a genealogy of postmetaphysical thinking," points out Habermas (2019, 41-42).

In reconstructing the "prehistory of postmetaphysical thinking," Habermas is informed by Amy Allen's "concept of 'genealogy,", which is based on Foucault's genealogy. Following the view of "rational reconstruction," the aim of Habermas $(2017,93)$ is "to show that this history can also be represented as a sequence of solutions to problems, whereas the genealogical perspective reveals the contingent historical constellations that made the actual learning process possible." This understanding of genealogy is not similar to Nietzsche's subversive intention, which is to undercut "the repressive features of a dominant mode of thought." For Habermas, postmetaphysical thinking has no alternative for doing philosophy today.

The hope of Habermas $(2019,70)$ in presenting the genealogy of postmetaphysical thinking is to make sense (einleuchten) why the "doom-laden" (verhängnisvoll) diagnosis and philosophical developments in the teachings of Carl Schmitt, Leo Strauss, Karl Löwith, and Martin Heidegger may hold as "advances in knowledge" (Erkenntnisfortschritte). But why a discourse on genealogy after all? ${ }^{18}$ Habermas may be correct in claiming that Nietzsche's expression, though far from being analytically clarified, should draw attention to the contingent traces that left behind an unfathomable context of origin that blends, to a certain extent, "captivating ideas." By choosing this illustration, Nietzsche thinks probably of the mythical destiny of family ties that continue to influence without reflection - the genealogy should expose the hidden flaw, which the genesis of Christianity has created in the legitimacy of Christian slave morality. ${ }^{19}$

Amy Allen informed Habermas of the differences between subversive, problematizing, and vindicative genealogies. Subversive genealogy proposes that the examined discourses or statements conceal "functions of maintaining power," which for the observer is at variance with the respective manifest content unquestioned by the participants (Habermas 2019, 70-71). In problematic genealogy, on the other hand, there is in mind "the pragmatic reference to addressees," who are critically unsettled with such enlightening analyses of the emerging context of their own convictions (aufklärenden Analysen des Entstehungskontextes ihrer eigenen Überzeugungen); in this respect, there exists a relationship with ideological criticism (Ideologiekritik), even if the expression 'genealogy' (as one finds in Foucault) is no longer carrying with it the Hegel-Marxist or Freudian "connotation of liberation through self-reflection" (Konnotation einer Befreiung durch Selbstreflexion).

Finally, with these two types, vindicatory genealogy only has for the time being (zunächst) the reference to the contingency of emerging context respectively of its own common ideas (jeweils eigener Ideen gemeinsam), and also the distance from a currently naïve understanding of the world and the self (auch den Abstand von der Naivität eine $>>$ geltenden $<<$ Welt - und Selbstverständnisses), "that disappears when its structures come to consciousness as a result of learning process" (die verschwindet, wenn dessen Strukturen als das Ergebnis eines Lernvorgangs zu Bewusstsein kommen). Habermas $(2019,71)$ cites as an example, and this is important to our present consideration, that a different light can be seen if we learn that the secular 
premises of postmetaphysical thinking are not due to the "deformed, distorted, buried premisses of Greek thought" (überformten, entstellten und verschütteten Prämissen griechischen Denkens) in Christianity during the 'Dark Middle Ages', but to a "longlasting theological discourse on faith and knowledge."

Reconstructing the learning process is not to do away with the "prerequisites of its persuasiveness," but to broaden the understanding of the emerging context in the manner of making visible not only the profits but also the costs of the learning process, Habermas continues. The function of the "intended genealogy" is not to justify but to be critical (Habermas 2017, 94). What is supposed to be fostered is "reflexive awareness of the contingency of the context of emergence of the background premises of the kind of theoretical and practical knowledge that for the present may claim rational acceptability," Habermas opines. Moreover, this is important: "This contextual awareness is generally expressed in the fallibilistic self-interpretation of science and philosophy because it keeps us alert to the possible context-dependence of prima facie universal propositions." This "fallibilistic consciousness" appears even relevant in "intercultural discourses." "The genealogy of one's own preunderstanding," continues Habermas, "fosters a willingness to decentre this background and to engage in mutual perspective-taking, a disposition which every party must bring to such a discourse." Genealogy elucidates the separate intellectual formations of both the secular and the religious and their complementarity evolving in the passage of this divergence. This is the reason why for Habermas, the intended genealogy "can present philosophy with a balance sheet of its learning processes and promote an awareness of how the two sides could complement each other through dialogue." Indeed, as Habermas $(2017,94)$ rightly puts it, the "genealogy of worldviews alerts postmetaphysical thinking to the fact that philosophy and religion have shared roots."

If the Catholic Church today wants to have a dialogue with the secular world, then this postmetaphysical thinking recommended by Habermas should be taken seriously. Only in adapting to the social and epistemological conditions of modernity that the religious interpretations of the self and the world can claim to be a part of "the legitimate discourses of modernity as the contemporary competing approaches of postmetaphysical thinking" (Cf. Habermas 2017, 78).

Again this bold claim of this new book of Habermas: "Die Moderne ist die Krise." The modern age is not only in crisis, but itself the crisis. However, in postmetaphysical thinking, salvation can come out from the crisis itself. We have seen above the drama of the separation of faith and reason, which prompted John Paul II in Fides et Ratio to make a "strong and insistent appeal" for faith and philosophy to recover their "profound unity" "without compromising their mutual autonomy." In public discourse, faith should be "matched by the boldness of reason." Moreover, thanks to Habermas' proposal of a postmetaphysical thinking, this appeal by the late John Paul II finds new impetus to carry out this dialogue further and without fear. Whatever be the outcome of this dialogue, which humanity today is in dire need of, only the future can tell. In the meantime, let me end this paper with a line from a German sociologist, Hans Joas (2017): “Eine Wissenschaft, die sich als Überwinderin des Glaubens versteht, und ein Glaube, der sich vor der Wissenschaft bedroht fühltdas sind zwei Seiten derselben Medaille. “20 


\section{NOTES}

1. "Die Arbeit an einem Buch und die Konzentration, die das erfordert, zehren auch an der Lebenszeit. So hätte die länger als ein Jahrzehnt währende Beschäftigung mit demselben Thema in der Einsamkeit und Freiheit eines Emeritiertendaseins leicht die Form eines bedrückenden Exerzitiums annehmen können (Habermas 2019, 16).

2. The later edition is the German original text. Every time we document the original text, we do it this way.

3. For our purposes, I am only citing the English translation.

4. In "Secularism and the Problem of Sincerity: A New Approach to Ritual," Seligman $(2015,1-21)$ has written an interesting discussion on this theme.

5. In "Modernity: An Unfinished Project," Habermas $(1997,39)$ mentions that during the late $5^{\text {th }}$ century, the term "modern" was first used to make a distinction between the "pagan and Roman past" and the present Christian world. Now during this time "modern" also is employed to distinguish between the Medieval and the new age of the Renaissance, Enlightenment and the advent of sciences and discoveries.

6. In his Third Meditation, Descartes $(1984,12)$ inquires whether God exists and, if he does, whether he can be a deceiver. Or else, without this knowledge, the certainty of anything else is impossible. Descartes $(1984,28)$ discovers that the idea of God is seen to have more "objective reality" than those which are only representations of "finite substances." He $(1984,29)$ says further that "if the objective reality does not reside in me, either formally or eminently, and hence that I myself cannot be its cause, it will necessarily follow that I am not alone in the world, but that some other thing which is the cause of this idea also exists." Besides the cogito, God exists primarily. Does God necessarily exist? In the Fifth Meditation, Descartes answers in the affirmative. A mountain and a valley, he observes, are mutually inseparable. So does God, whose existence is inseparable from him. The necessity of his existence is not an imposition of thought. One cannot freely think of God's non-existence (Descartes 1984, 46). He $(1984,47)$ continues saying, "Apart from God, there is nothing else of which I am capable of thinking such that existence belongs to its essence." Undeniably for Descartes, God is not a fiction of the mind.

7. The Cogito is the positive element of Descartes' philosophizing. As Chappell $(2005,24)$ puts it, "It is a method of deflating the philosophical overambition and complacency that Descartes finds, above all, in the medieval schoolmen."

8. When I was working for my Doctorate in Philosophy at the Ecclesiastical Faculty of Philosophy of the University of Santo Tomas, Manila, I made an attempt to explore the philosophy of Edith Stein and her contribution to the dialogue between faith and reason (see Estafia 2011).

9. Pope John Paul II (1998, n. 74) says, "We see the same fruitful relationship between philosophy and the word of God in the courageous research pursued by more recent thinkers, among whom I gladly mention, in a Western context, figures such as John Henry Newman, Antonio Rosmini, Jacques Maritain, Etienne Gilson, and Edith Stein and, in an Eastern context, eminent scholars such as Vladimir S. Soloviev, Pavel A. Florensky, Perr Chaadaev, and Vladimir N. Lossky." 
10. The modern spirit is different from both Greek and Medieval thought, whose dominant theme is the problem of being. What marks the difference, however, between the Greek and the Medieval is that the former knows no revelation while the latter assumes the problem of being in view of revealed truths (see Stein 2002, 4; 2006, 12 13).

11. It appears that this philosophy is "like a rigid system of concepts" (wie ein starres Begriffssystem) being handed down as a "dead possession" (toter Besitz) from one generation to another (Cf. Stein 2002, 13).

12. Just allow me to write here the original text in German: "Es sind aber doch bis heute schon Ausgrabungsarbeiten geleistet worden, die eine vergessene Welt - eine reiche, heiß bewegte, voll lebendiger und fruchtbarer Keime - zu Tage gefördert haben" ["But already up to the present, excavation work has been carried out, bringing to light a forgotten world - a rich, hotly moving, full of living and fertile germs" (Stein 2006,14). Translations mine.

13. "Und es hat im Zusammenhang dieser Weise von Rationalität eine Kultur entwickelt, die in einer bisher nirgendwo in der Menschheit gekannten Weise Gott aus dem öffentlichen Bewußtsein verbannt, sei es, daß er ganz geleugnet, sei es, daß seine Existenz als unbeweisbar, unsicher und daher eben dem subjectiven Entscheiden zugehörig als jedenfall öffentlich irrelevant eingestuft wird" (Marcelo Pera et al. 2005, 66).

14. In his controversial lecture at the University of Regensburg in Germany on September 12, 2006, Benedict XVI focuses on the relationship between reason and faith. The lecture is not about Islam, as perceived by some in the Muslim world. In fact, the title of the lecture is "Faith, Reason and the University: Memories and Reflections." In the said lecture, Benedict XVI affirms that God is Logos, creative reason itself. This is his summary of the testimony of the Bible and the early Christian Church. What is contrary to reason, he claims, is contrary to God's nature. Christianity must be reasonable in order for it to be consistent with God's rational character. Faith should be balanced by reason, for if not, it will just be a kind of "religious fanaticism." Moreover, reason without faith leads to skepticism, cynicism, and in the end, a nihilism that brings despair (see Allen, Jr. 2008. 20-22). In his intellectual life, Joseph Ratzinger (Benedict XVI) has always been preoccupied with the relationship between faith and politics (Glaube und Politik). There is a book recently published in German which is a collection of Ratzinger's writings on such themes (see Benedikt XVI./Ratzinger 2018). In the Foreword of Die Freiheit befreien, Pope Francis writes that the main theme of Ratzinger's thoughts has always been like that: the relationship between faith and politics ("Das Verhältnis zwischen Glaube und Politik ist seit jeher ein Hauptthema im Denken Joseph Ratzingers - Benedikt XVI..." (Ratzinger 2018, 7). There is another interesting collection of Benedict XVI's writings that deal with the theme on God and Reason (see Benedikt XVI 2007).

15. I have not read the whole chapter, but I presume Habermas is referring to Jacgues-Bénigne Bossuet (1627-1704), who is a French bishop, considered as an influential spokesman for the rights of the French church against papal authority.

16. "... liegt die Rettung aus dem universalen Sog der kapitalistischen Verdinglichung nicht in der Rückwendung zu den römischen Wurzeln des Katholizismus oder den Klassikern beziehungsweise Ursprüngen der griechischen 
Philosophie, sondern in der revolutionären Entbindung der in der Moderne aufgestauten, aber einstweilen entstellten Potentiale“ (Habermas 2019, 40).

17. In this paper, I am only translating the German text liberally. Once I am not certain of my own translation with some words or phrases, I am placing the original text in parenthesis, or if necessary, the whole German text appears in the endnote.

18. , Warum überhaupt von einer $>>$ Genealogie $<<$ die Rede sein soll “ (Habermas 2019, 72).

19. „Nietzsche eingeführte, aber keineswegs analytisch geklärte Ausdruck sollte, wenn ich recht verstehe, auf die kontingenten Spuren aufmerksam machen, die ein undurchschauter Entstehungszusammenhang verblendenden, gewissermaßen gefangennehmenden Ideen hinterlässt. Nietzsche denkt wohl bei der Wahl dieses Bildes an die mythische Schicksalshaftigkeit von unreflektiert fortwirkenden Familienbanden - die >>Geneologie < sollte den verborgenen Makel bloßlegen, den die Entstehungsgeschichte des Christentums in der Geltung der christlichen $>>$ Sklavenmoral $<<$ verursacht hat" (Habermas 2019, 70).

20. Since only recently that I got a copy of Hans Joas' book, I still have to find out from which page one can find this quotation. I only quoted it directly from the back cover of this book (see Joas 2017). My translation: "A science, which understands itself as an overcomer or conqueror of faith, and a faith that feels itself threatened before science, are two sides of the same medal (or coin)."

\section{REFERENCES}

Allen, John L., Jr. 2008. Ten things Pope Benedict XVI wants you to know. Bandra, Mumbai: St. Paul Press.

Benedikt XVI./Ratzinger, Joseph. 2018. Die Freiheit befreien: Glaube und politik im dritten Jahrtausend. Hg. Pierluca Azzaro und Carlos Granados. Freiburg im Breisgau: Verlag Herder GmbH.

Benedikt XVI./Ratzinger, Joseph and Habermas, Jürgen. 2006. Dialectics of secularization: On reason and religion. Translated by Brian McNeil, C.R.V and Edited with a Foreword Florian Schuller. San Francisco: Ignatius Press; 2011. Dialektik der Säkularisierung: Über Vernunft und Religion. Freiburg im Breisgau: Verlag Herder.

Benedikt XVI./Ratzinger, Joseph. 2007. Gott und die Vernunft: Aufruf zum Dialog der Kulturen. Augsburg: Sankt Ulrich Verlag GmbH.

Boethius. 1999. The consolation of philosophy. Translated by P.G. Walsh. New York: Oxford University Press, Inc.

Chappell, Timothy. 2005. The inescapable self: An introduction to Western philosophy. London: Weidenfeld \& Nicolson.

Descartes, Rene. 1984. Meditations on the first philosophy. Translated by John Cottingham. In The Philosophical Writings of Descartes, Vol. II. Cambridge: Cambridge University Press.

Estafia, Jose Conrado A. 2011. Edith Stein on being human: Her contribution to the dialogue between faith and reason. Unpublished Dissertation, University of Santo Tomas, Manila. 
Foucault, Michel. 1984. The Foucault reader. Edited by Paul Rabinow. New York: Pantheon Books.

Habermas, Jürgen. 2019. Auch eine geschichte der philosophie, Band I and Band II. Berlin: Suhrkamp Verlag.

Habermas, Jürgen. 2017. Postmetaphysical thinking II. Essays and replies. Translated by Ciaran Cronin. Cambridge: Polity Press; 2012. Nachmetaphysisches Denken II. Aufsätze und Repliken. Berlin: Suhrkamp Verlag.

Habermas, Jürgen. 1997. Modernity: An Unfinished Project. In Habermas and the Unfinished Project of Modernity: Critical Essays on the Philosophical Discourse of Modernity. Edited by Maurizio Passerin d' Entréves and Seyla Benhabib. Cambridge, Massachusetts: The MIT Press.

Joas, Hans. 2017. Die macht des Heiligen. Eine alternative zur geschichte von der Entzauberung. Berlin: Suhrkamp Verlag.

John Paul II. 1996. Agenda for The Third Millennium. Translated by Alan Neame. London: Harper Collins Publishers, Inc.

John Paul II. 1979. Easter Vigil and other poems. Translated by Jerzy Peterkiewicz. London: Hutchinson and Co., (Publisher) Ltd.

John Paul II. 1998. Encyclical Letter Fides et Ratio. Libreria Editrice Vaticana.

John Paul II. 2005. Memory and identity: Conversations at the dawn of a millennium. New York: Rizzoli International Publications, Inc.

John Paul II. 1992. Post-Synodal Apostolic Exhortation Pastores Dabo Vobis. Libreria Editrice Vaticana.

John Paul II/Wojtyla, Karol. 1979. The acting person. Translated by Andrzej Potocki. London: D. Reidel Publishing Company.

Kant, Immanuel. 2001. Basic writings of Kant. Edited with introduction by Allen W. Wood. New York: The Modern Library.

Lacey, A. R. 1996. A dictionary of philosophy. $3^{\text {rd }}$ Revised Edition. New York: Barnes and Noble.

Seligman, Adam B. 2015. Secularism and the problem of sincerity: A new approach to ritual. Interdisciplinary Journal for Religion and Transformation in Contemporary Society I (I): 1-21.

Stein, Edith. 2002. Finite and eternal being: An attempt at an ascent to the meaning of being. Translated by Kurt F. Reinhardt. Washington, D.C.: ICS Publications; 2006. Edith Stein Gesamtausgabe (ESGA) 11/12. Endliches und ewiges Sein, Versuch eines Aufstiegs zum Sinn des Seins. Ed. Andreas Uwe Müller. Freiburg: Herder.

Taylor, Charles. 2007. A secular age. Cambridge: The Belknap Press.

Pera, Marcelo and Ratzinger, Joseph. 2005. Ohne wurzeln: Der ralativismus und die krise der Europäischen kultur. Augsburg: Sankt Ulrich Verlag GmbH.

Weigel, George. 2001. Witness to hope: The biography of Pope John Paul II. New York: Harper Collins Publishers, Inc. 